and tontent had been resorted to in rain, and that not anco only, but repeatedly, I am indeed sceptical of the proance onis, delaying the radical cure; for I believe that priety of delaying the radical cure; for I believe that nothing short of spoed red her that great amount of ease and comfort which she has ever since experienced.

Wirtsworth, Derbyehiro, Septombar 1855.

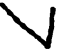

\section{ON CANCER.}

\section{By THOMAS POPE, Esq.}

Caxore, that crudele opprobium medicorum, will form the subject of this paper.

Of all the ills to which the human frame is liable, this is most poignant, and it has hitherto been considered incurable. From the idea of its incurability, I am happy to say that I dissent. What? Is an humble individual like myself to assert the curability of cancer? Yes, when the cause, the grand organ, is only functionslly diseased; but if the complaint organ, is only functionally diseased; but if the deranged, it is then, and only then, in my opinion, incurable. This may be considered tantamount to asserting not only the curability but the prerention of cancer. What a happy era will that be when it shall continue no longer a stigma medicorum, but be their captive, and ultimately annihilated! These are bold words; but, I hope, no less bold than true. Now let us come to close quarters with the enemy; let us see if we can discover its rise. Its progress and end we too painfully know.

It is a blood-disease, and, like all such, is generated within, and caused by a vitiated secretion of bile. What its peculiar nature is, we shall never attain to ; for who can tell what is the peculiar nature of the different skin-diseases and other disorders arising from contaminated blood? A greater refinement of chemistry may ultimately disclose much; but in our present state of knowledge, we know not how this or that peculiar blood disease is produced. This much I hsve reason to believe, that if the liver secrete a purely healthy bile, there can be no blood-disease internally generated, and, I had well nigh said, externally.

In my apprenticeship in the year 1797, my master and inoculated, in one day, upwards of three hundred of all ages, but mostly children. Their diet consisted of farinaceous and other vegetable productions, to the exclusion of all alcoholic drinks and animal food. The consequence was, that only one died, and from his own misconduct; for he infringed the rules both dietetically and medically; the others passed through the disorder according to the purity of the blood, or, in other words, according to the observance of the rules. Some few had it in the confluent form, but the majority had only two or three pustules; many had only one, and that at the place of the insertion of the virus; and five or six had the blood in so pure a state as to bid defiance to the poison, till they were allowed a more nutritious and stimulating diet. The medical part of the treatment consisted in a calomel pill repeated twice a week. The time of preparation was three weeks.

A few years ago, I vaccinated seven children of the same family. Fire took the infection the first time, the other two resisted; and though I repeated the insertion of the virus till the sixth time, with a week or fortnight's intermission, I could not succeed; but after a month's allowance of a rather generous diet, it took effect. Here I had every reason to believe that the purity of the blood was the cause of the success.

Cancer, gout, rheumatism, tubercle (shall I say cramp?), and all the various skin-diseases, arise from contaminated blood, and this contamination is the effect of a vitiated secretion of bile; so that to prevent impure blood, a watchful eye must be kept on the biliary secretion. When the liver is in a state of health the blood is pure, and health and strength are the happy consequences; but when its cecretion is deranged, this or that disorder will arise; and if the same canses that produce this derangement are con- tinued, the subetance of the liver becomes changed, and whatever be the disorder so produced, it is either fatal of Whatever be the disorder 80 produced, it its disorders which itself, or brings with it in graph it may not be amiss, for the prevention of hydrophobia to suggest the strictest attention, for some months, to the biliary secretion.

It may be asked, how is cancer formed? Before answering the question, I mean to confine myself to the description of scirrhus, to the exclusion of encephaloid cancer, and of fungus hrmatodes, which are alike fatal blooddiseases.

There is no part of the body exempt from the attacks of cancer, internally as well as externally; but it has proference for some parts more than others, as the breasts and uterus in females, the lips and genitals in man Its first appearance is in the form of a small hard knob, a deposit from the blood of the cancerous virus generated in the from the blood of the cancerous virus generated in the place of deposit is some injured part. How long it may remain stationary, depends altogether on the state of the liver as to its generation of the morbific matter. If that be suspended, and that may be for years, it is stationary; indeed I have known some who have lived to extreme old age in such a state, and who have not died thereof at last; so that its progress depends on the condition of the biliary secretion. As the poison is generated, so it is carried generally to its original place of deposit, whereby the knob enlarges. Now, the deposit is an effort of nature for the continuance of life; for if the poison were not eliminated from the system, death would soon ensue. This does not, at last, happen from the poison in the system, but from its ravages in the part; for as the poison becomes more acrid, so the disorder progresses, till at last the scirrhus bursts, and becomes an open ulcer, with its horrid lancinating pains, and horrible and peculiar fotor.

At whatever stage of the disorder medical advice be had, the liver should be our polar star; and if that be only functionally affected, a cure may be hoped for: but if, on the contrary, it be organically affected, the only aid we can render is palliative. In tho former case, no progress will ensue, and it may be safely taken out; but in the latter, death will thereby be hastened.

As prevention is better than cure, another question may be asked, and that is, how is cancer prevented ? The natural corollary from the foregoing is to keep the liver healthy, and every worthy member of our Association recognises this state too well to need description.

A proper diet is of the first importance; but here let us remark, that as constitutions vary so much the diets do also; for the old saying may be here applied, "What is one man's meat is another's poison." The different temperaments roquire different diets, that of the scrofulous always generous. The urinary and alvine excretions should be diligently observed, because they are infallible guides. Nothing deranges the function of the liver more than grief, and this, of all the causes of cancer, is the most prolific; therefore it should always be avoided with the greatest care, especially as it leads to no good, and incapacitates us from properly meeting and overcoming its cause.

The next cause is constipation; and whatever disturbs the chylopoietic function, and excites a greater determination of blood to these parts; for the greater part of that blood has to pass through the liver in its return to the heart, so that if more be sent there than can be returned to the right auricle, the consequence is, that it is retarded in the liver, which becomes congested thereby, and, according to its congestion, so is the bile, and thus this secretion becomes vitiated. So that when the liver only receives that proportion of blood which can readily be returned to the heart, the bile is pure; and, e contraria parte, the longer the blood is congested therein, the more is it restricted, as wo all know that the bile is made from that blood which roturns by the vena porte to the heart, through the liver. Temperance, well regulated exercise, food easy of digestion, a contented and happy mind, and whatover conduces to a 


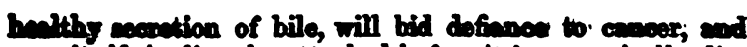
an is if the liver be attacked before it be organically. dis oriened; thenefore, the ovitanda are, excose in diet, and aimnli, mbetances hard of digestion, constipation, inaction, deppandeney, late suppers, and whatover occasions a great datermination of blood to the stomach, and the other parts concerned in digestion.

Iram the foregoing, I think it deducible that cancer may be prorented, under certain circumstances, radically cured, and thes this our opprobrium, and the direst affliction that can amil the human race be, like the small-pox, annihilated. Here some may say, Is the small-pox annihilated? To which I answer, God has given man the power to anvihilate it; and He will, I am persuaded, give us the power to conquer every disorder to which we are now

Cleobury Mortimer, Salop, 4th September, 1855.

\section{FDITOR'S IHETTER BOX.}

\section{THE YORK MEETING AND THE IVEST SOMERSET BRANCH. \\ Ietrer froy Francts Henty Woodforde, M.D.}

Sin,-I am instructed by the Council of this Branch to send you the following copy of a memorial addressed by the Branch Council of the Executive Council which holds its first meeting this day at Birmingham, with the request that you will cause it to be inserted in the Jorraral. I am, etc.,

Sept. 7th, 1855 Francis HenRy Woodforde, Hon. Secretary.

" To the President of the Council and Members of the Executive Council of the Provincial Mredical and Surgical Association.

" Gentueven,-The Council of the West Somerset Branch, fully concurring in the declaration of opinion signed by $45: 3$ members of the Association, and presented at the generul meeting lately held at York; and believing that it is only by carrying out the principles therein contained that the Association can exercise that beneficial influence on the medical pro. fession for which it was established, or continue to confer honour on its founder, - view with extreme regret and surprise the resolutiou of the General Council which postponed the reception of the document so numerously and influentially signed until the end of the second day's meeting, thereby in effect preventing its being considered and discussed.

"They consider the tendency of the proceedings at York to be essentially retrograde, and calculated to produce the decay of an Association which might and ought to become the embodiment of the whole profession, for its adrancement in utility and dignity.

"They therefore respectfully express the hope that the Executive Conncil will for the present suspend, as far as may be necessary, the carrying out the resolutions of the York meeting, composed as it was of so small a proportion of the members; and proceed to take such steps as will put them in possession of the views of the whole Association on the said declaration of opimion, which now stands recorded in the minutes of its proceedings." Signed, by order of the Branch Council,

Taunton, Sept. 6th, 1855.

Fancis HenRy Woodforde, Hon. Secretary.

REASONS FOR RESIGNING THE MEMBERSHIP OF THE PBOVINCIAL MEDICAL AND SURGICAL ASSOCIATION.

LETTER FBOY T. HERBERT BARKER, M.D.

Sir,-I have sent my resignation as a member of the Provincial Medical and Surgical Association to the Secretary, Dr. Williams; and have come to the determination to take this step on the following grounds.

1. Although. I voted in the minority at the Oxford moeting, the character of the JourNal has so greatly improved under the able editorship of Dr. Cormack, that I am fully reconciled to the change; and, instead of feeling, with Sir Charles Hentings, that the Oxford meeting was a most disastrons one, I have long since regarded it as the commencement of a vastly improved state of things. These improvements were gradually being developed, in spite of systematic and rexatious opposition; but the culers at Worcester are evidently oppoeed to all progress.
2. I think that Dr. Cormeale riahly deserwed the moet enteful thanks of the Association, rather than the rough usage which he met with at York.

3. A memorial which had been signed by nearly one-fourth of the members of the Association was ignored by the Council at the York meeting; and our estimable metropolitan brethrea (whom wo ought to hail as necessary and powerful allies) were sadly slighted and disreganded.

4. As long as the representative principle is not fully and fairly carried out, the Association must oontinue to be governed by a clique, and its only good will be of a social and convivial cheracter.

5. The Secretaryship of the Association has been re-established at Worcester-a place remote from the centre of business and usefulness.

Under these circumstances, I retire from the Association in dismay and disgust; and, in doing so, I beg publicly to record my gratitude to Dr. Cormack for his indefatigable exertions-exertions which, I believe, have been appreciated by the many, although frustrated and despised by the few.

$$
\text { I am, otc., } \quad \text { T. HERBERT Barkar. }
$$

Bedford, Sept. 11th, 1855.

\section{DR. CORMACh'S RESIGNATION}

Letter froy A. Hattuand, Esq.

SIR,-As a member of the Provincial Medical and Surgical Association, I cannot receive the intelligence of your resignation without expressing to you my extreme regret at the conduct which has been observed towards you by certain persons, and which appeared more especially at the York mecting.

I have ever viewed your transactions with the society, both as our Secretary and Editor of our JounNaI, as highly conducive to the welfare of the Association, which mainly by your strennous efforts has been restored to respectability; and made to claim and assume a place in the estimation of the literary world, which, under the old regime, it did not possess, and which it never could have attained, had you not infused into its Jounvar that new intellectual blood, which has improved and instructed your readers, and swelled the list of members.

I deplore, therefore, that for this act of good service you. should have met with such an ungrateful return; but whilst I do so, I also hope that the many hundred associates who feel with me will rally around you, and thus show to the world that the medical men of England refuse to be ruled by a clique; that we desire to be represented, according to the true understanding of that term; and not dictated to by self-clected and narrow. minded Committees.

With my best thanks for the able manner in which you have conducted our Jounsal, and with hearty wishes for your happiness and professional success,

Bridgewater, 9th Sentember, 1855.

$$
\text { I am, etc., A. HavmuND. }
$$

\section{DR. COWAN'S RESIGNATION}

Letter froji Charles Cowan, M.D.

Sun,-Believing that the proceedings of the Anuual Meeting recently held at York (which involve the removal of the General Secretary from London to Worcester, and the retention of an exclusive provinciality in the name and working of the Association), are opposed to the interests of the medical profession, insulting to our London colleagues, and directly at variance with the wishes of a large majority of the members, I decline to continue any longer connected with the Provincial Medical and Surgical Association. I desire to make this known through: the Joursal.

Reading, September 12th, 1855. I am, etc., Charues Coway.

MR. HEADLAM'S MEDICAL REFORM BILL: REPORT OF THE COMMITTEE OF THE ASSOCIATION OF GENERAL MEDICAL PRACTITIONERS IN IRELAND.

LETTER FROM JoHs RYAN, M.D.

StR,-I have been instructed to forward the enclosed Report, with a request that you will have the kindness to cause its insertion in the the ASsocintion Medical JodrRat. I am, etc., Jors RYMs, Hon. Seenetary.

Dublin, Sept. 10ch, 1856.

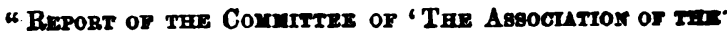

